\title{
Quantification of milk yield and composition changes as affected by subclinical mastitis during the current lactation in sheep
}

\author{
Ana Martí De Olives, ${ }^{* 1}$ J. R. Díaz, ${ }^{*}$ M. P. Molina, $†$ and C. Peris $†$ \\ *Departamento de Tecnología Agroalimentaria, Escuela Politécnica Superior de Orihuela, Universidad Miguel Hernández de Elche, \\ 03312 Orihuela, Spain \\ †Instituto de Ciencia y Tecnología Animal, Universidad Politécnica de Valencia, 46022 Valencia, Spain
}

\begin{abstract}
The aim of this work was to quantify, on a half-udder basis, the changes in ewe milk yield and composition caused by unilateral subclinical mastitis within the current lactation. Fluctuations due to production level, infection severity, time from the onset of infection, and lactation curves were also studied. Yield and composition of milk from half-udders of unilateral infected ewes were compared between them and with a set of healthy halves using a mixed model. The experiment was completed with a whole-udder approach on the same animals. To test the effect of intramammary infection (IMI) in the $7 \mathrm{wk}$ following the onset of infection, 20 ewes that acquired unilateral subclinical mastitis during lactation and 40 healthy ewes were used. Another group of 20 unilaterally infected ewes from wk 1 of lactation and other 40 healthy ewes were studied to test the effect of IMI on lactational milk yield and composition. The individual milk loss in ewes infected during lactation was $15 \%$ for the 7 wk following the onset of infection, and $6.6 \%$ more milk was produced by the uninfected half to compensate milk lost by the infected half. Lactational milk yield loss in ewes infected from wk 1 postpartum was $17 \%$. The changes in milk yield were noticed from the week of infection diagnosis. The production level of animals influenced the milk yield changes caused by IMI in such a way that the more productive ewes lost more milk, although these losses were proportional to their production level. On the other hand, infection severity affected milk loss between glands, being more pronounced as somatic cell count increased. A clear decrease of lactose content and casein:protein ratio due to subclinical IMI was observed and it remained throughout the postinfection period. Improving udder health status is necessary to maintain milk production and quality in dairy ewes during lactation
\end{abstract}

Received May 6, 2013.

Accepted August 16, 2013.

${ }^{1}$ Corresponding author: ana.marti@umh.es
Key words: subclinical mastitis, ewe milk yield, ewe milk composition, lactation

\section{INTRODUCTION}

Mastitis causes loss of milk yield and modification of main components as a result of damage in the mammary secretory tissue (Burriel, 1997; Burriel and Wagstaff, 1998). Previous studies on dairy sheep reported that subclinical IMI by CNS is the major factor affecting flock milk yield (Gonzalo et al., 2002; Leitner et al., 2008; Giadinis et al., 2012) and it has negative effects on milk cheese-making (Leitner et al., 2004; Martí-De Olives et al., 2011). In contrast to clinical mastitis, subclinical mastitis is imperceptible, and affected udders are therefore milked into the bulk milk tank. Frequently the glands are not treated and milk yield losses persist during the subsequent lactation (Gonzalo et al., 2004). Infection severity, type of bacteria, and unilateral or bilateral character ( 1 or 2 infected glands, respectively) determine the consequences of subclinical IMI on ewe milk yield (Gonzalo et al., 2002). A relationship between lactation stage and subclinical mastitis has also been reported such that milk yield is more correlated to SCC at the end of lactation than at the beginning (Arias et al., 2012).

Milk production losses caused by subclinical IMI in sheep have been demonstrated by different approaches at the individual level (Saratsis et al., 1999; Gonzalo et al., 2002; Leitner et al., 2003) as well as the half-udder level (Leitner et al., 2004; Cuccuru et al., 2011). However, quantifying this effect with precision is difficult. The conventional whole-udder approach requires a data set of numerous samples to account for the large and significant individual variation (Gonzalo et al., 1994, 2002). Moreover, when only one gland is infected, the effect of mastitis can be underestimated because of possible compensatory milk production from uninfected half (Leitner et al., 2004).

Subclinical IMI also leads to a modification of main milk components. In ovine milk, the lactose content decreases with IMI (Díaz et al., 1996; Burriel, 1997; 
Bianchi et al., 2004), mainly because of the reduced synthesis capacity of damaged tissue (Burriel, 1997) but also because of lesser availability of its precursor, glucose, due to competition for energy between secretor cells and those with phagocyte functions (Rulquin, 1997). Fat and casein are modified in some way or another depending on the magnitude of milk yield reduction. The reduction of milk volume as a result of IMI is frequently greater than the decrease in fat and casein synthesis, resulting in a concentration of those components in milk (Schultz, 1977; Burriel, 1997). In addition, lactose can amplify this concentration effect because it is an osmotic regulator of milk, its decrease resulting in a reduction of milk volume (Munro et al., 1984; Burriel, 1997). On the other hand, the components that come from blood, such as whey proteins, normally increase because of the higher permeability of the blood-milk barrier during an IMI (Díaz et al., 1996; Leitner et al., 2003; Bianchi et al., 2004).

The purpose of this study was to quantify the changes in ewe milk yield and composition caused by unilateral subclinical mastitis within the current lactation, using both half-udder and whole-udder approaches. Fluctuations due to factors such as production level, severity of infection, time from the onset of infection, and lactation week were also tested. Possible compensation of milk loss in the infected gland by an increase of milk production in the uninfected gland was also evaluated.

\section{MATERIALS AND METHODS}

\section{Animals and Experimental Design}

This work was carried out during 2 annual lactations on the experimental farm flock of Manchega ewes of the Institute for Animal Science and Technology of the Polytechnic University of Valencia (Valencia, Spain). The trial was initiated with 145 ewes without signs of clinical mastitis (76 and 69 ewes for the first and second year, respectively). Ewes were in first parity $(\mathrm{n}=33)$ and second and greater parities $(\mathrm{n}=112)$. The animals were stabled throughout the lactation period and were machine milked twice daily at 0830 and $1730 \mathrm{~h}$ from d 3 after lambing. In each year, the trial was conducted over 16 wk. All births occurred within 4 wk, so all animals were analyzed over 12 wk of lactation. The presence of IMI in each gland was tested by bacteriological and SCC measures twice a week during the first $15 \mathrm{~d}$ after lambing and then once a week for the next $14 \mathrm{wk}$. Milk yield and main components were analyzed once a week, both on complete udders at morning and evening machine milkings and on half-udders by emptying the gland by hand after an oxytocin injection. Analysis of complete udder milk was made beginning in wk 1 post- partum and analysis of half-udder milk was made from wk 2 of lactation, because of the difficulty of completely emptying the glands during the first days of lactation.

To increase the incidence of IMI, and consequently the number of cases to study, 2 management practices were applied. The first was the immersion of all teats in a bacterial suspension of Staphylococcus simulans (5 $\times 10^{7} \mathrm{cfu} / \mathrm{mL}$ ) between wk 4 and 8 after lambing. The immersions were practiced on 4 alternating days, at the morning and evening milkings ( 8 milkings), and immediately before application of the milking unit. The second practice was no dipping of teats after milking throughout the trial.

\section{Bacterial Challenge}

The bacterial suspension was made from a Staph. simulans strain obtained from a gland with subclinical mastitis from a commercial flock. Staphylococcus simulans is part of the group of CNS that are considered opportunist microorganisms normally found on healthy teat skin as well as on the hands of milkers. Consequently, Staph. simulans may easily colonize the teat canal and infect the mammary gland. The bacterial suspension used to dip the teats was prepared according to Hogan et al. (1990). Stock cultures of Staph. simulans were stored at $-20^{\circ} \mathrm{C}$ in $50 \%$ glycerin. A $6-\mathrm{mL}$ tube of trypticase soy broth (TSB) was inoculated from a vial of stored stock culture and incubated at $37^{\circ} \mathrm{C}$ for $7 \mathrm{~h}$. One milliliter of this starter culture was used to inoculate $500 \mathrm{~mL}$ of TSB, which was then incubated for 16 to $18 \mathrm{~h}$ at $37^{\circ} \mathrm{C}$ on a gyratory shaker. Cells were pelleted by centrifugation, washed twice with a $0.1 \%$ water solution of proteose-peptone (no. 3, Difco Laboratories, Detroit, MI), and resuspended in proteose-peptone. A standard plate count was conducted on the stock suspension before it was stored at $5^{\circ} \mathrm{C}$. The plate count was used to determine the dilution required to prepare daily challenge suspensions containing $5 \times 10^{7} \mathrm{cfu} / \mathrm{mL}$ in TSB. The challenge suspension was prepared immediately before each of the 8 milkings.

\section{Bacteriological and SCC Analysis}

To obtain milk samples for bacteriological analysis, teats were carefully cleaned with $70 \%$ ethanol, and the first 3 streams of foremilk were discarded. Approximately $10 \mathrm{~mL}$ of milk was collected aseptically from each gland before the morning milking. Samples were kept at $4^{\circ} \mathrm{C}$ for up to $12 \mathrm{~h}$ until bacteriological analysis. Twenty microliters of each sample was plated on blood agar plates (5\% washed sheep erythrocytes; bioMérieux, Lyon, France). The plates were incubated aerobically at $37^{\circ} \mathrm{C}$ and examined at $24 \mathrm{~h}, 48 \mathrm{~h}$, and $7 \mathrm{~d}$. Cultures 
with 5 or more identical colonies were considered positive for IMI. A new IMI in a half udder was diagnosed when the same bacterial species was isolated from 2 consecutive samples positive for IMI $(\geq 250 \mathrm{cfu} / \mathrm{mL})$. A gland diagnosed with IMI was considered infected from the first sampling in which the culture was positive for IMI. Bacteria were identified according to the National Mastitis Council recommendations (Harmon et al., 1990). Identification of staphylococci was carried out using commercial micromethods (API Staph; bioMérieux). Milk samples for SCC determination were preserved with bronopol $(0.1 \%)$ and analyzed by a Fossomatic 90 (Foss Electric, Hillerød, Denmark) in all samples taken for bacteriological analysis. Samples remained under refrigeration for 24 to $48 \mathrm{~h}$ before being analyzed (IDF, 1995).

\section{Sampling and Analysis}

Whole-udder milk yield was determined during morning and evening milkings. Half-udder milk yield was estimated by using the productive potential method such that a first intravenous injection of 3 IU of oxytocin was administered to animals after the milking and the glands were completely emptied by hand milking. After a period of $4 \mathrm{~h}$, a second injection of oxytocin (3 IU) was administered and glands were completely emptied again, and milk of each gland was collected separately. The milk obtained by this method was measured using graduated test tubes. To estimate the quantity of milk that each gland could synthesize per day (productive potential of milk, PPM), the milk quantity obtained within $4 \mathrm{~h}$ was multiplied by 6 .

From each milk sample obtained from both complete udders and half udders, a $50-\mathrm{mL}$ aliquot was transferred into a plastic storage jar and stored at $4^{\circ} \mathrm{C}$ until analysis. Milk composition (fat, protein, true protein, casein, whey protein, lactose, and DM) was determined by midrange infrared spectroscopy using a MilkoScan FT120 (Foss Electric). The mean percentage of components in milk samples from the whole udder were determined by mean percentages obtained from morning and evening milkings weighted by volume of milk.

\section{Grouping of Ewes for Data Analysis}

Depending on the moment of first IMI diagnosis, the infected ewes were divided into 2 groups to be analyzed within 2 separate studies. The first group included ewes that were free of IMI at postpartum wk 1 and acquired unilateral subclinical mastitis during lactation. The second group comprised ewes that were diagnosed with unilateral subclinical mastitis at postpartum wk 1 . In both cases, a set of healthy ewes (controls) was selected to be blocked into trios with infected ewes. In each trio, 1 ewe was infected and the other 2 were healthy throughout the trial and similar in parity, milk production, and lactation state at the moment of selection.

Study of Ewes Infected During Lactation. Twenty unilaterally infected ewes and 40 ewes free of IMI were included in this analysis. Ewes with an udder health status inappropriate for the experiment (e.g., clinical mastitis, bilateral infection) and those infected too late $(<5$ wk postinfection) were excluded. Parities of the 20 ewes were as follows: first parity, $\mathrm{n}=10$; second and greater parity, $\mathrm{n}=10$. The ewes acquired IMI between wk 3 and 10 of lactation and remained infected for the rest of the trial. The average period during which they were permanently infected was 6.5 wk. The variable "infection week" (IW) was defined as the time (wk) relative to the moment of first IMI diagnosis. Thus, IW $=-1$ corresponded to the week before the first diagnosis, IW $=0$ was the week of first diagnosis, week IW $=1$ was the week immediately after first diagnosis, and so on to IW $=6$ (after which, there were too few animals to be analyzed). Therefore, 2 experimental periods were established: a preinfection period of $2 \mathrm{wk}(\mathrm{IW}=-2$ and -1$)$ and a postinfection period of $7 \mathrm{wk}(\mathrm{IW}=0,1,2,3,4,5$, and 6$)$. The objectives of this study were to estimate the changes in milk yield and composition with improved precision by use of preinfection values to correct the postinfection values (Rajala-Schultz et al., 1999) and to research the possible compensatory milk production of milk loss in the infected gland by the uninfected gland.

Study of Ewes Infected in Wk 1 Postpartum. Twenty ewes with unilateral subclinical mastitis at wk 1 postpartum and 40 ewes free of IMI with which they were blocked were included. This study did not include a preinfection period. Ewes with an udder health status inappropriate for the experiment (e.g., clinical mastitis, bilateral infection) were excluded. Parities of the 20 ewes were as follows: first parity, $\mathrm{n}=9$; second and greater parity, $\mathrm{n}=11$. The objective of this study was to establish the curves of lactation and to estimate the lactational milk yield and composition changes due to IMI.

\section{Statistical Analysis}

Statistical analyses were performed using SAS software (SAS Institute, 2011). Several mixed-effects models (by the Mixed procedure) were used to study the effects of different factors on $\log _{10}$ SCC, individual milk yield, PPM of half udders, and milk composition parameters. To analyze data of ewes infected during lactation at the half-udder level in the preinfection period, the following mixed model was used: 


$$
\begin{gathered}
\mathrm{Y}_{\mathrm{ijklmn}}=\mu+\mathrm{YEAR}_{\mathrm{i}}+\mathrm{EIS}_{\mathrm{j}}+\mathrm{E}_{\mathrm{k}}\left(\mathrm{YEAR} \times \mathrm{EIS}_{\mathrm{ij}}\right) \\
+\mathrm{GIS}_{1}+\mathrm{GLA}_{\mathrm{m}}\left(\mathrm{E} \times \mathrm{GIS}_{\mathrm{kl}}\right)+\mathrm{IW}_{\mathrm{n}}+\mathrm{YEAR} \\
\times \mathrm{EIS}_{\mathrm{ij}}+\mathrm{E} \times \mathrm{GIS}_{\mathrm{kl}}+\mathrm{EIS} \times \mathrm{GIS}_{\mathrm{jl}}+\mathrm{EIS} \times \mathrm{GIS} \\
\quad \times \mathrm{IW}_{\mathrm{jln}}+\mathrm{EIS} \times \mathrm{GIS} \times \mathrm{YEAR}_{\mathrm{jli}}+\mathrm{e}_{\mathrm{ijklmn}},
\end{gathered}
$$

where $Y_{\mathrm{ijklmn}}=$ records of each variable; $\mu=$ general mean; $\mathrm{YEAR}_{\mathrm{i}}=$ year effect $(\mathrm{i}=1$, first year; $\mathrm{i}=2$, second year); EIS $_{\mathrm{j}}=$ fixed effect of ewe infectious status $\left(\mathrm{j}=1\right.$, healthy ewes; $\mathrm{j}=2$, infected ewes); $\mathrm{E}_{\mathrm{k}}$ (YEAR $\times$ EIS $\left._{\mathrm{ij}}\right)=$ random effect of the ewe nested in YEAR $\times \operatorname{EIS}_{\mathrm{ij}}$ interaction $(\mathrm{k}=1,2,3, \ldots, 60) ; \mathrm{GIS}_{1}=$ fixed effect of gland infectious status $[1=1$, infected glands from infected ewes (type A glands) or healthy glands from healthy ewes (type $\mathrm{C}$ glands); $1=2$, healthy contralateral glands to A glands (type B glands) or healthy contralateral glands to C glands (type D glands); letters $\mathrm{C}$ and $\mathrm{D}$ were randomly assigned to each gland of healthy ewes; $\mathrm{GLA}_{\mathrm{m}}\left(\mathrm{E} \times \mathrm{GIS}_{\mathrm{kl}}\right)=$ random effect of gland nested in $\mathrm{E} \times \mathrm{GIS}_{\mathrm{kl}}$ interaction $(\mathrm{m}=1,2,3$, $\ldots, 120) ; \mathrm{IW}_{\mathrm{n}}=$ fixed effect of infection week $(\mathrm{n}=0$, $1,2,3, \ldots, 6) ;$ YEAR $\times$ EIS $_{\mathrm{ij}}=$ year $\times$ ewe infectious status interaction; $\mathrm{E} \times \mathrm{GIS}_{\mathrm{kl}}=$ ewe $\times$ gland infectious status interaction; EIS $\times$ GIS $_{j 1}=$ ewe infectious status $\times$ gland infectious status interaction; EIS $\times$ GIS $\times$ $\mathrm{IW}_{\mathrm{jln}}=$ ewe infectious status $\times$ gland infectious status $\times$ infection week interaction; EIS $\times$ GIS $\times \mathrm{YEAR}_{\mathrm{jli}}=$ ewe infectious status $\times$ gland infectious status $\times$ year interaction; and $\mathrm{e}_{\mathrm{ijklmn}}=$ residual effect.

In the postinfection period, the mixed model used to analyze data of ewes infected during lactation at half udder level was the same as [1] with adding the mean value of preinfection period as a covariate $(\mathbf{C O V})$.

At the individual level, the model used to analyze data of ewes infected during lactation in the preinfection period was

$$
\begin{gathered}
\mathrm{Y}_{\mathrm{ijkl}}=\mu+\mathrm{YEAR}_{\mathrm{i}}+\mathrm{EIS}_{\mathrm{j}}+\mathrm{E}_{\mathrm{k}}\left(\mathrm{YEAR} \times \mathrm{EIS}_{\mathrm{ij}}\right) \\
+\mathrm{IW}_{\mathrm{l}}+\mathrm{YEAR} \times \mathrm{EIS}_{\mathrm{ij}}+\mathrm{EIS} \times \mathrm{IW}_{\mathrm{jl}}+\mathrm{e}_{\mathrm{ijkl}},
\end{gathered}
$$

At the individual level, the model used in the postinfection period to analyze data of ewes infected during lactation was the same as [2] with addition of the mean value of preinfection period as $\mathrm{COV}$.

The models used to analyze data of ewes infected from wk 1 postpartum were the same as above ([1] and $[2])$. The COV was not included because of the absence of a preinfection period.

To evaluate the influence of infection severity and milk production level on the magnitude of milk losses, both in the study of ewes infected during lactation and that of ewes infected from postpartum week, several regression analyses were done with the Reg procedure (SAS Institute, 2011). A file with mean values of infected ewes was used to make the regressions. The 2 dependent variables were (1) for each infected ewe, the mean value of the difference between the PPM of healthy and infected glands throughout the postinfection period (PPMDm); and (2) for each infected ewe, PPMDm expressed in relative terms (PPMDm\%), calculated by dividing PPMDm by the postinfection mean PPM of healthy gland. The independent variables were calculated differently depending on the group of ewes considered. For ewes infected during lactation, the independent variables were, for each ewe, the mean value of PPM of both glands in the preinfection period $(\mathbf{P P M m})$ and the mean value of $\log _{10} \mathrm{SCC}$ of the infected gland during the postinfection period (Log$\left.{ }_{10} \mathrm{SCCm}\right)$. For ewes infected from wk 1 postpartum, the independent variable $\log _{10} \mathrm{SCCm}$ was calculated in the same way as calculated for ewes infected during lactation, but PPMm was calculated, for each ewe, as the mean value of PPM of healthy gland during the first 3 measurements of PPM. A total of 12 regression equations were obtained, such that for each dependent variable (PPMDm or PPMDm\%), 3 regression equations were obtained for each study: 2 regressions with 1 variable (PPMm or $\left.\log _{10} \mathrm{SCCm}\right)$ and 1 regression with both variables.

\section{RESULTS}

\section{Infection Characteristics of Ewes}

In the study of ewes infected during lactation, infections occurred between wk 3 and 10 from lambing. Most of the infections, 13 out of 20 isolates, were caused by the same bacteria used in the immersions (Staph. simulans); other infections were caused by Staphylococcus epidermidis (3 isolates), and Streptococcus spp., Staphylococcus xylosus, Micrococcus spp., and Streptococcus bovis ( 1 isolate each). In the group of ewes infected from wk 1 postpartum, the most frequently isolated microorganisms were Staph. simulans (10 isolates), followed by Streptococcus spp. (2 isolates); and Staph. epidermidis, Klebsiella pneumoniae, Staphylococcus caprae, Staphylococcus capitis, Serratia marcescens, Staphylococcus aureus, Staph. xylosus, and Staphylococcus spp. (1 isolate each).

\section{Effect of Subclinical IMI at Half-Udder Level}

In the preinfection period in the study of ewes infected during lactation, year had a significant effect on all variables, but the $Y E A R \times E I S \times G I S$ interaction effect was not significant. The effect of $E I S \times G I S$ in- 
Table 1. Least squares means $( \pm \mathrm{SEM})$ of the considered parameters affected by gland health status ${ }^{1}$ during the postinfection period, in ewes infected during lactation (Lact.) and in wk 1 postpartum (postpartum)

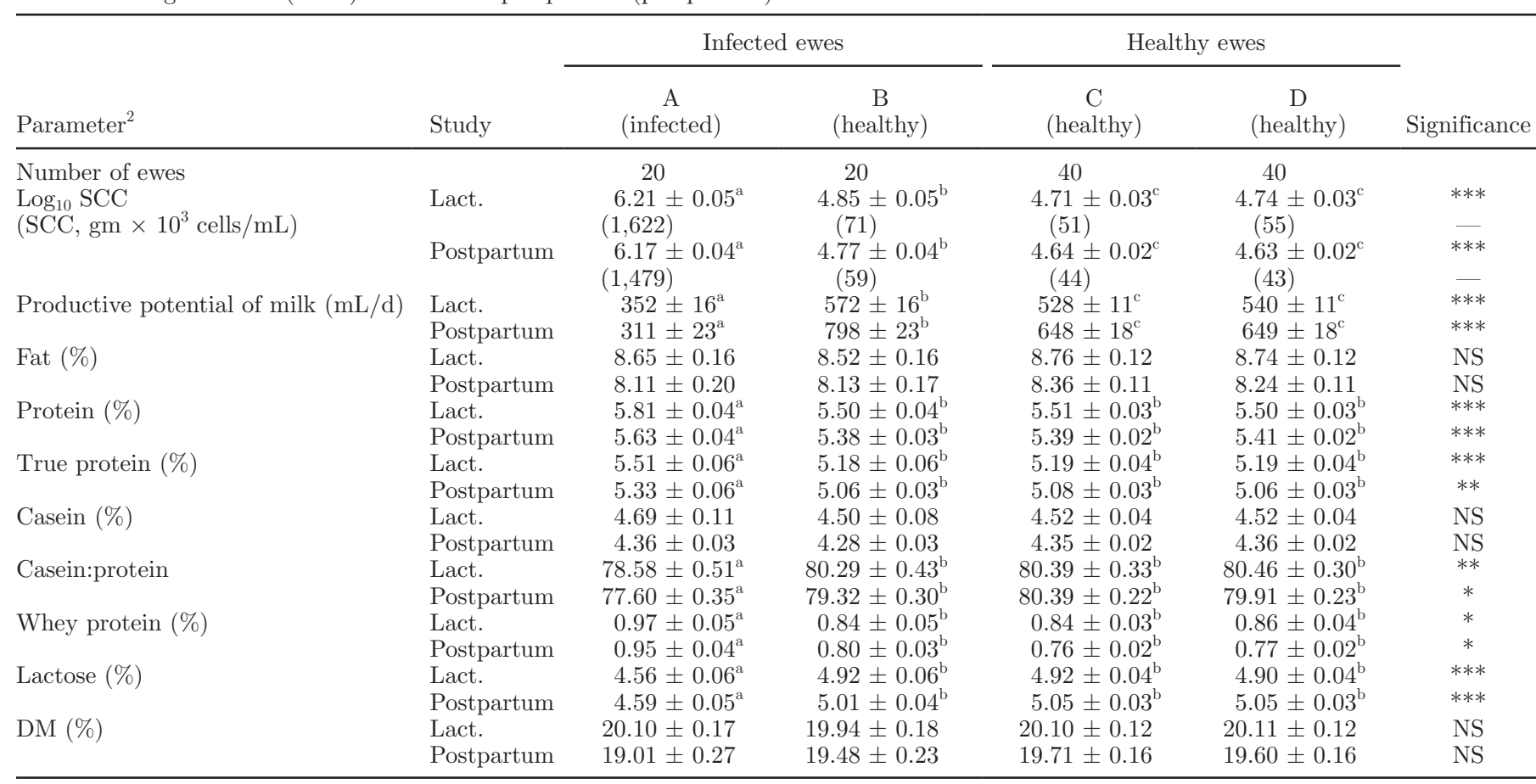

${ }^{\mathrm{a}-\mathrm{c}}$ Means within a row with different superscripts differ.

${ }^{1} \mathrm{~A}=$ infected glands; $\mathrm{B}=$ healthy glands contralateral to A glands; $\mathrm{C}=$ healthy glands of healthy control ewes; $\mathrm{D}=$ healthy glands of healthy control ewes, contralateral to $\mathrm{C}$ glands.

${ }^{2} \mathrm{gm}=$ geometrical mean.

*** $P<0.001 ;{ }^{* *} P<0.01 ; * P<0.05$.

teraction was not significant either, meaning that no significant differences existed between gland types A, $\mathrm{B}, \mathrm{C}$, and $\mathrm{D}$, even though $\mathrm{A}$ and $\mathrm{B}$ belonged to ewes that would be unilaterally infected in the postinfection period, and $\mathrm{C}$ and $\mathrm{D}$ belonged to ewes that would remain healthy in the postinfection period.

In the postinfection period, in ewes infected during lactation and in ewes infected in wk 1 postpartum, year significantly affected several variables but the $Y E A R$ $\times E I S \times G I S$ interaction effect was not significant. However, the EIS $\times$ GIS interaction had a significant effect on $\log _{10} \mathrm{SCC}$, PPM, protein, true protein, casein:protein ratio, whey protein, and lactose.

Table 1 shows least squares means $( \pm \mathrm{SEM})$ of the considered parameters and their significance levels as affected by gland health status during the postinfection period. In both studies, $\log _{10} \mathrm{SCC}$ had a significantly higher mean value in infected glands than in healthy glands and was significantly higher in milk of B healthy glands (contralateral to infected ones) than in milk from $\mathrm{C}$ and $\mathrm{D}$ healthy glands. Nevertheless, the 3 values (in B, C, and D glands) were very low and typical of glands free of IMI. In both studies, the average $( \pm$ SEM $)$ PPM in infected glands (A glands) was smaller than that in all healthy glands $(\mathrm{B}, \mathrm{C}$, and D glands). During $7 \mathrm{wk}$ postinfection in ewes infected during lactation, the milk yield of the infected glands was $38 \%$ lower than the milk yield of healthy glands. A significant $6.6 \%$ average PPM difference was established between B healthy glands $(572 \mathrm{~mL} / \mathrm{d})$ and C and $\mathrm{D}$ glands (average of $534 \mathrm{~mL} / \mathrm{d}$ ), indicating that healthy glands produced more milk when their contralateral glands were infected than when their contralateral glands were healthy.

When we analyzed ewes infected in wk 1 postpartum, the mean PPM of infected glands during 11 wk of lactation was $61 \%$ less than that obtained in the healthy glands of the same animals (A glands: $311 \mathrm{~mL} / \mathrm{d}$ vs. B glands: $798 \mathrm{~mL} / \mathrm{d}$ ). Moreover, the PPM of healthy $\mathrm{B}$ glands was higher than that of healthy glands from control ewes (B glands: $798 \mathrm{~mL} / \mathrm{d}$ vs. C glands: 648 $\mathrm{mL} / \mathrm{d}$ and $\mathrm{D}$ glands: $649 \mathrm{~mL} / \mathrm{d}$ ).

With respect to the chemical composition of milk (Table 1), we observed a similar trend in ewes infected during lactation and in ewes infected in wk 1 postpartum, showing a significantly higher protein, true protein, and whey protein in infected glands (A) than in healthy glands (B, C, and D). Lactose and the casein:protein 
ratio were lower in infected glands, whereas fat, casein, and DM did not differ between glands.

Table 2 shows the regression equations that correlate the productive level of animals and infection severity (SCC level) with the PPM losses as affected by IMI, in both ewes infected during lactation and in ewes infected from postpartum wk 1 . In equations [1] and [1'] of Table 2, a significant relationship exists between PPMm and the mean PPM difference between glands of infected animals during the postinfection period (PPMDm). Nevertheless, when PPMDm was expressed in percentage terms (PPMDm\%), the regression analysis did not give a significant result (equations $[4]$ and $\left[4^{\prime}\right]$ ). In the regression equation between PPMDm and $\log _{10} \mathrm{SCCm}$ on the ewes infected during lactation (equation [2]), the coefficient of determination was significant but low $\left(\mathrm{R}^{2}\right.$ $=0.25$ ) and that for PPMDm\% (equation [5]) was not significant. In the analysis of ewes infected from wk 1 postpartum (equations $\left[2^{\prime}\right]$ and $\left[5^{\prime}\right]$ ), the determination coefficients for PPMDm and PPMDm\% were significant $\left(R^{2}=0.63\right.$ and $R^{2}=0.40$, respectively). However, the determination coefficients were better when the regressions included both variables (PPM and $\log _{10} \mathrm{SCC}$; Equations [2], [3'], [6], and [6']).

Figure 1 shows the evolution of PPM in the 4 groups of glands (A, B, C, and D) of ewes infected during lactation in the $7 \mathrm{wk}$ following the onset of infections. In $\mathrm{IW}=0$, when infections were diagnosed, an abrupt decrease in PPM of infected A glands was observed, and B glands presented a higher PPM than did C and $\mathrm{D}$ glands. Because the effect of the $E I S \times G I S \times I W$ interaction on PPM was not significant, the differences

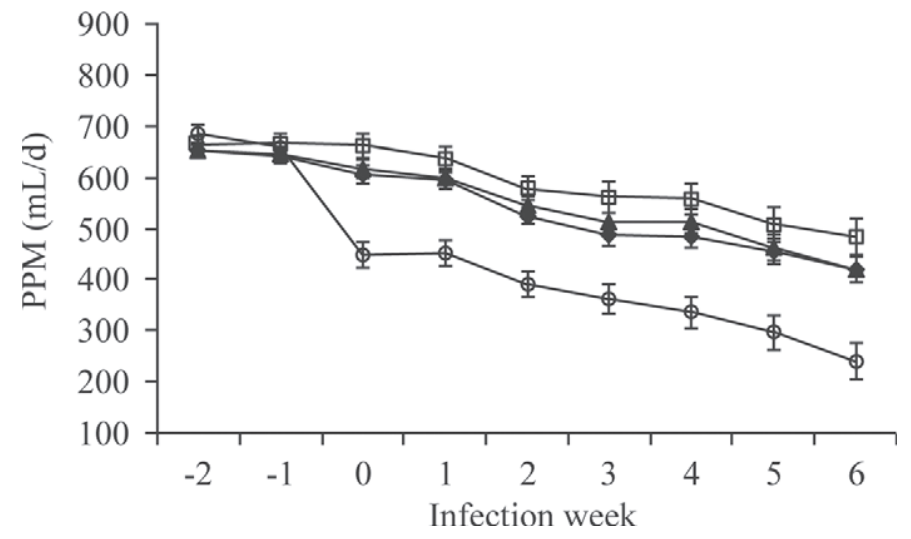

Figure 1. Productive potential of milk (PPM) from glands of ewes infected during lactation. Values are LSM \pm SEM indicated by vertical bars of infected A glands ( $\bigcirc$ ), B contralateral to A glands ( $\square$ ), C glands of healthy control ewes $(\mathbf{\Lambda})$, and D glands of healthy control ewes $(\downarrow)$, before the onset of infection [infection week $($ IW $)<0$ ] and after the onset of infection $(\mathrm{IW} \geq 0)$.

between glands did not vary during the postinfection period.

In the group of ewes infected in wk 1 postpartum, the evolution of PPM of the 4 groups of glands (A, B, $\mathrm{C}$, and D) during lactation period is shown in Figure 2. The effect of IMI was evident from the first week when PPM was measured (wk 2 after lambing), with a difference of approximately $500 \mathrm{~mL} / \mathrm{d}$ between infected A glands and healthy B glands. From lactation wk 2 to 3 , PPM in healthy glands (B, C, and D) increased slightly or stayed the same and thereafter showed decreasing trend until the end of the lactating period. However, in the infected A glands, PPM decreased permanently

Table 2. Regression equations for the mean value of productive potential of milk (PPM) difference between infected and healthy glands of infected animals during postinfection period, expressed in absolute terms (PPMDm) and in relative terms (PPMDm\%)

\begin{tabular}{|c|c|c|c|c|}
\hline Variable & Regression equation $^{1}$ & $\begin{array}{c}\text { Pairs. } \\
\text { (no.) }\end{array}$ & $\mathrm{R}^{2}$ & Significance \\
\hline \multirow[t]{2}{*}{$\begin{array}{l}\text { PPMDm } \\
(\mathrm{mL} / \mathrm{d})\end{array}$} & $\begin{array}{l}\text { [1] Lact. PPMDm }=0.5 \times \mathrm{PPMm}-107 \\
{\left[1^{\prime}\right] \text { Postpartum PPMDm }=0.8 \times \mathrm{PPMm}-214}\end{array}$ & $\begin{array}{l}20 \\
20\end{array}$ & $\begin{array}{l}0.58 \\
0.62\end{array}$ & $\begin{array}{l}* * * \\
* * *\end{array}$ \\
\hline & $\begin{array}{l}{[2] \text { Lact. PPMDm }=170 \times \log _{10} \mathrm{SCCm}-845} \\
{\left[2^{\prime}\right] \text { Postpartum PPMDm }=369 \times \log _{10} \mathrm{SCCm}-1,794}\end{array}$ & $\begin{array}{l}20 \\
20\end{array}$ & $\begin{array}{l}0.25 \\
0.63\end{array}$ & $\begin{array}{c}* \\
* * *\end{array}$ \\
\hline \multirow[t]{2}{*}{ PPMDm\% } & $\begin{array}{l}\text { [4] Lact. PPMDm } \%=0.02 \times \mathrm{PPMm}+24 \\
{\left[4^{\prime}\right] \text { Postpartum PPMDm } \%=0.03 \times \mathrm{PPMm}+36}\end{array}$ & $\begin{array}{l}20 \\
20\end{array}$ & $\begin{array}{l}0.11 \\
0.10\end{array}$ & $\begin{array}{l}\text { NS } \\
\text { NS }\end{array}$ \\
\hline & $\begin{array}{l}\text { [5] Lact. PPMDm } \%=10 \times \log _{10} \mathrm{SCCm}-27 \\
{\left[5^{\prime}\right] \text { Postpartum PPMDm } \%=27 \times \log _{10} \mathrm{SCCm}-105}\end{array}$ & $\begin{array}{l}20 \\
20\end{array}$ & $\begin{array}{l}0.14 \\
0.40\end{array}$ & $\begin{array}{l}\mathrm{NS} \\
* *\end{array}$ \\
\hline
\end{tabular}

${ }^{1}$ In ewes infected during lactation (Lact.), PPMm = mean value of both glands PPM during the preinfection period; in ewes already infected in wk 1 postpartum (postpartum), PPMm = mean value of healthy gland PPM during the first 3 checks; $\log _{10}$ SCCm = mean value of the infected gland during postinfection period.

*** $P<0.001$; ** $P<0.01 ;{ }^{*} P<0.05$. 


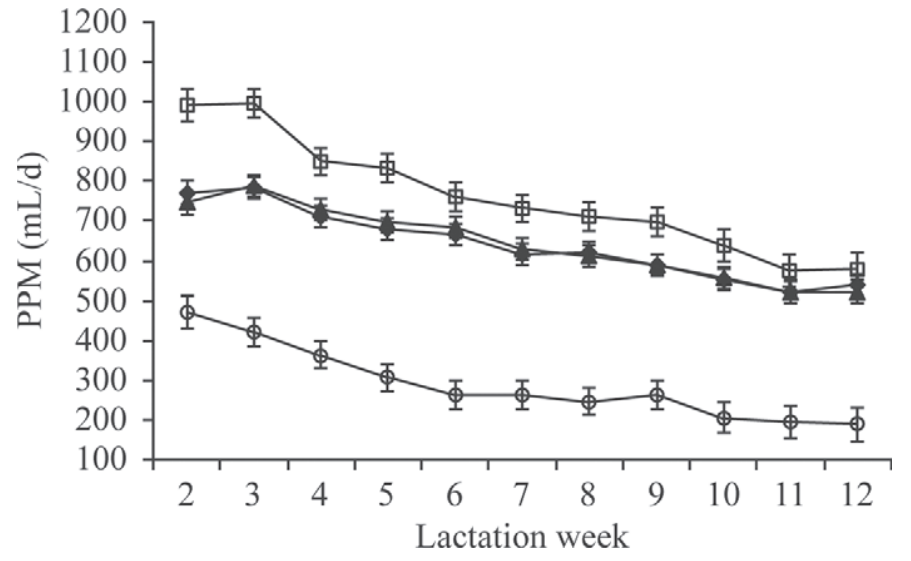

Figure 2. Productive potential of milk (PPM) from glands of ewes already infected in wk 1 postpartum. Values are LSM \pm SEM indicated by vertical bars of infected A glands $(\mathrm{O})$, B contralateral to A glands $(\square)$, C glands of healthy control ewes $(\boldsymbol{\Lambda})$, and D glands of healthy control ewes $(\diamond)$.

from wk 2 of lactation. In spite of these differences at the beginning of lactation, the $E I S \times G I S \times I W$ interaction was not statistically significant.

For $\log _{10} \mathrm{SCC}$ and the milk components affected by IMI, we observed a difference between glands from the week in which the infection was diagnosed, both in ewes infected during lactation and those infected in wk 1 postpartum. The interaction $E I S \times G I S \times I W$ was not significant for chemical parameters: differences between glands were constant from the week of first IMI diagnosis until the end of study periods. Only in ewes infected during lactation was this interaction significant for $\log _{10} \mathrm{SCC}$ (Figure 3). A decreasing trend of $\log _{10} \mathrm{SCC}$ was observed in A glands from the week of infection to the end of lactating period, whereas a typical increasing trend was observed in the B, C, and D glands. Nevertheless, in the ewes already infected in postpartum wk 1, the effect of $E I S \times G I S \times I W$ interaction was not statistically significant for $\log _{10} \mathrm{SCC}$ (Figure 4).

\section{Effect of Subclinical IMI at the Individual Level}

During the preinfection period at the individual level, the year effect was statistically significant for several variables in the ewes infected during lactation, but the $Y E A R \times E I S$ interaction effect and the EIS effect was not significant for any variable.

In the postinfection period, in both studies, year significantly affected several variables but the $Y E A R$ $\times E I S$ interaction effect was not significant for any of them. On the other hand, EIS significantly affected $\log _{10} \mathrm{SCC}$, milk yield, casein:protein ratio, and lactose. Table 3 gives the mean values of parameters determined during the postinfection period in individual milk of infected and healthy control ewes, in both studies.

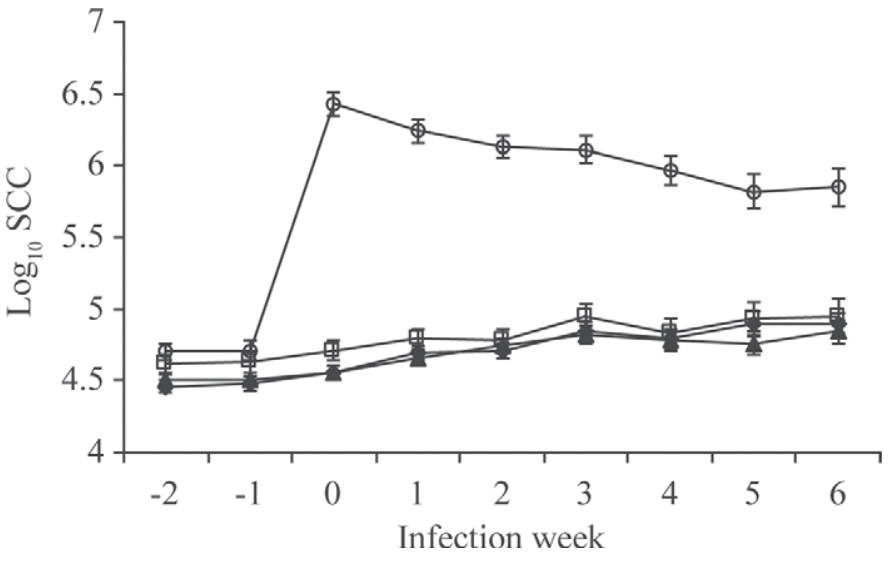

Figure 3. $\log _{10}$ SCC in milk from glands of ewes infected during lactation. Values are LSM \pm SEM indicated by vertical bars of A glands ( $\bigcirc)$, B contralateral to A glands $(\square)$, C glands of healthy control ewes $(\mathbf{\Lambda})$, and D glands of healthy control ewes $(\downarrow)$ before the onset of infection [infection week $($ IW $)<0$ ] and after the onset of infection $(\mathrm{IW} \geq 0)$.

$\log _{10} \mathrm{SCC}$ presented a significantly higher mean value in infected ewes than in healthy ones, which was smaller on a whole-udder basis than on the half-udder level, because the milk came from 2 glands and the cell content of the infected gland was diluted. The difference in individual milk production between infected and healthy ewes was $15 \%$ in ewes infected during lactation and $17 \%$ in ewes already infected in wk 1 postpartum. All milk components followed the same pattern as those at the half-udder level, but the differences in wholeudder milk were moderate compared with those at the half-udder level because of the dilution effect. Only the casein:protein ratio and lactose showed significant differences due to IMI at the individual level (Table 3).

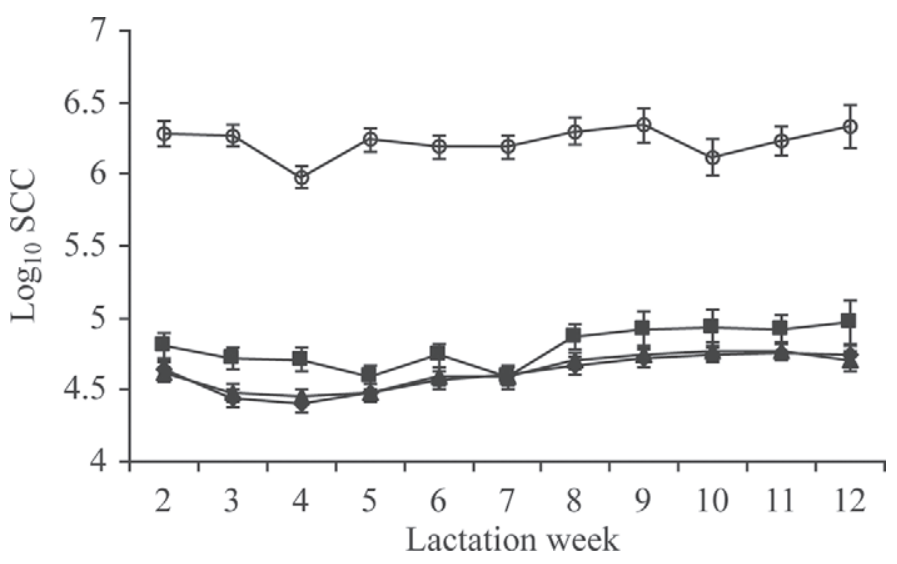

Figure 4. $\log _{10}$ SCC in milk from glands of ewes already infected in wk 1 postpartum. Values are LSM \pm SEM indicated by vertical bars of A glands (O), B contralateral to A glands $(\square)$, C glands of healthy control ewes $(\boldsymbol{\Lambda})$, and D glands of healthy control ewes $(\bullet)$. 
Table 3. Least squares means $( \pm \mathrm{SEM})$ of the considered parameters in individual milk as affected by ewe health status during the postinfection period, both in the study of ewes infected during lactation (Lact.) and in ewes already infected in wk 1 postpartum (postpartum)

\begin{tabular}{|c|c|c|c|c|}
\hline Parameter & Study & Infected ewes & Healthy ewes & Significance \\
\hline Number of ewes & & 20 & 40 & \\
\hline \multirow{2}{*}{$\begin{array}{l}\mathrm{Log}_{10} \mathrm{SCC} \\
\left(\mathrm{SCC}, \mathrm{gm} \times 10^{3} \text { cells } / \mathrm{mL}^{1}\right)\end{array}$} & Lact. & $\begin{array}{l}5.80 \pm 0.04^{\mathrm{a}} \\
(631)\end{array}$ & $\begin{array}{l}4.95 \pm 0.03^{\mathrm{b}} \\
(89)\end{array}$ & *** \\
\hline & Postpartum & $\begin{array}{l}5.64 \pm 0.04^{\mathrm{a}} \\
(427)\end{array}$ & $\begin{array}{l}4.91 \pm 0.03^{\mathrm{b}} \\
(81)\end{array}$ & $* * *$ \\
\hline \multirow[t]{2}{*}{ Milk yield (mL/d) } & Lact. & $897 \pm 50^{\mathrm{a}}$ & $1,053 \pm 35^{\mathrm{b}}$ & $* *$ \\
\hline & Postpartum & $982 \pm 87^{\mathrm{a}}$ & $1,186 \pm 65^{\mathrm{b}}$ & $*$ \\
\hline \multirow[t]{2}{*}{ Fat $(\%)$} & Lact. & $7.08 \pm 0.26$ & $7.35 \pm 0.19$ & NS \\
\hline & Postpartum & $7.09 \pm 0.18$ & $7.25 \pm 0.14$ & NS \\
\hline \multirow[t]{2}{*}{ Protein (\%) } & Lact. & $5.69 \pm 0.13$ & $5.61 \pm 0.09$ & NS \\
\hline & Postpartum & $5.39 \pm 0.08$ & $5.38 \pm 0.06$ & NS \\
\hline \multirow[t]{2}{*}{ True protein (\%) } & Lact. & $5.50 \pm 0.13$ & $5.39 \pm 0.09$ & NS \\
\hline & Postpartum & $5.06 \pm 0.09$ & $5.05 \pm 0.07$ & NS \\
\hline \multirow[t]{2}{*}{ Casein $(\%)$} & Lact. & $4.50 \pm 0.11$ & $4.48 \pm 0.08$ & NS \\
\hline & Postpartum & $4.14 \pm 0.07$ & $4.21 \pm 0.05$ & NS \\
\hline \multirow[t]{2}{*}{ Casein:protein } & Lact. & $78.03 \pm 0.54^{\mathrm{a}}$ & $79.70 \pm 0.39^{\mathrm{b}}$ & $* *$ \\
\hline & Postpartum & $76.78 \pm 0.43^{\mathrm{a}}$ & $78.44 \pm 0.31^{\mathrm{b}}$ & $* * *$ \\
\hline \multirow[t]{2}{*}{ Whey protein (\%) } & Lact. & $0.98 \pm 0.06$ & $0.92 \pm 0.04$ & NS \\
\hline & Postpartum & $0.90 \pm 0.04$ & $0.84 \pm 0.03$ & NS \\
\hline \multirow[t]{2}{*}{ Lactose (\%) } & Lact. & $4.67 \pm 0.07^{\mathrm{a}}$ & $4.94 \pm 0.05^{\mathrm{b}}$ & $* *$ \\
\hline & Postpartum & $4.80 \pm 0.06^{\mathrm{a}}$ & $5.06 \pm 0.04^{\mathrm{b}}$ & $* * *$ \\
\hline \multirow[t]{2}{*}{$\mathrm{DM}(\%)$} & Lact. & $18.48 \pm 0.39$ & $18.81 \pm 0.28$ & NS \\
\hline & Postpartum & $18.01 \pm 0.25$ & $18.50 \pm 0.20$ & NS \\
\hline
\end{tabular}

\footnotetext{
${ }^{\mathrm{a}, \mathrm{b}}$ Means within a row with different superscripts differ.

${ }^{1} \mathrm{gm}=$ geometrical mean.

${ }^{* * *} P<0.001 ;{ }^{* *} P<0.01 ; * P<0.05$.
}

The results from the analysis at the individual level confirmed, in both studies, the trend over time observed at the half-udder level, showing an abrupt decrease in milk production in infected ewes compared with healthy ewes starting in the week of infection diagnosis. During the postinfection period, milk yield in both studies decreased in parallel because the $E I S \times I W$ interaction was not statistically significant. The effect of IMI on casein:protein ratio and lactose content was evident from the week of infection diagnosis in the 2 studies, and the differences between infected and healthy ewes were constant throughout the postinfection period, the $E I S \times I W$ interaction being nonsignificant. Only in the study of ewes infected during lactation was this interaction significant for $\log _{10} \mathrm{SCC}$. A decreasing trend was observed on infected ewes from the week of infection to the end of lactating period, whereas a typical increasing trend was observed in the B, C and D glands. Nevertheless, in the ewes already infected in wk 1 postpartum, the effect of $E I S \times I W$ interaction was not statistically significant for $\log _{10} \mathrm{SCC}$.

\section{DISCUSSION}

\section{Infection Characteristics of Ewes}

Various CNS are the most abundantly occurring isolates associated with subclinical mastitis in sheep flocks
(Leitner et al., 2001, 2004; Gonzalo et al., 2002). The CNS are usually ignored by farmers and veterinarians because they are not considered as major pathogenic bacteria. However, in the present study, CNS infection, mainly that caused by novobiocin-sensitive CNS (Staph. simulans and Staph. epidermidis) induced the inflammatory response, reflected by a high SCC, which is consistent with previous findings in sheep (Ariznabarreta et al., 2002; Gonzalo et al., 2002; Leitner et al., 2003).

\section{Effect of IMI on Milk Yield}

In the present work, the PPM of infected glands was $38 \%$ less than that of healthy glands over the $7 \mathrm{wk}$ following the onset of infection. This difference was much greater $(61 \%)$ when infection was already present in wk 1 postpartum and persisted throughout the lactation period studied (from wk 2 to 12). Note that the PPM values obtained in both studies cannot be compared, because no preinfection period was evaluated in the ewes already infected in wk 1 postpartum. In other words, the PPM of A and B glands might already have been different before the first measurement of PPM, which would result in overestimation of the true PPM difference between glands. However, 38 to $61 \%$ is a large difference, allowing us to hypothesize, first, that the reduction in milk yield could be greatest when IMI occurs in early lactation, as reported in cows (Lucey 
and Rowlands, 1984; Rajala-Schultz et al., 1999); and second, that the higher value of PPM could be due to persistent mastitis acquired in one or more previous lactations, as has been described in cows (RajalaSchultz et al., 1999; Sloth et al., 2003).

The results of the study in which ewes were infected during lactation showed an individual milk loss of $14 \%$ if calculated on a half-udder basis (the addition of halves of infected ewes, $924 \mathrm{~mL} / \mathrm{d}$, vs. the addition of halves of control ewes, 1,068 mL/d). This was consistent with the $15 \%$ milk loss obtained from the whole-udder approach. Thus, actual milk loss as a result of unilateral subclinical IMI in the current study could be quantified as $15 \%$ for the $7 \mathrm{wk}$ following the onset of infections. This result was consistent with a previous work in which a similar approach was used (Peris et al., 1996), and in general with other studies that report losses of milk yield by unilateral subclinical mastitis from 3 to $14.4 \%$, depending on the methods used to estimate it, on the bacteria involved in, and the time of infection permanency (Dario et al., 1996; Gonzalo et al., 2002). The individual milk yield lost by ewes already infected in wk 1 postpartum was $17 \%$, very similar to the $15 \%$ lost by ewes infected during lactation. This finding is in contrast with the great difference obtained at the half-udder level between the 2 types of analysis (38 vs. $61 \%$ ). It is possible that ewes with mastitis from the first lactation week were higher yielding animals before infection compared with their healthy herdmates, according to what generally occurs in cows (Gröhn et al., 1995; Rajala-Schultz et al., 1999; Wilson et al., 2004), which would reduce the estimated individual differences due to IMI.

Comparison of PPM of healthy glands from control ewes with that of healthy glands in infected ewes allowed us to demonstrate a compensation phenomenon previously suggested in sheep (Peris et al., 1996; Leitner et al., 2003), whereby when one half is infected, the other half compensates by producing more milk, so that the loss of individual milk is ameliorated. The greater amount of milk that is produced by the healthy gland to compensate for the lower milk quantity of the infected gland could entail an excessive effort for the whole udder. The results of the present research, with $6.6 \%$ more milk obtained in the uninfected gland during the postinfection period, confirm with statistical significance the results of Peris et al. (1996), in which an increase of $7.4 \%$ was obtained. In that research, the results were not statistically significant, probably because of the limited data (only 8 unilateral infected animals were studied). This compensatory effect (the increase from the healthy gland to compensate for the infected gland) was estimated to be $13 \%$ in cows (Woolford, 1985).
In the study of ewes already infected in wk 1 postpartum, we cannot state that the higher PPM of B glands of infected ewes compared with glands of control sheep was due to a compensatory effect, because no preinfection values were available. Healthy glands of infected ewes might have had higher milk yields than control ewes before the unilateral infections were acquired.

\section{Effect of IMI on Milk Composition and SCC}

Several components of milk were affected by subclinical IMI, the effects being established with higher statistical significance at the half-udder level than at the individual level. The reason may be the absence of individual factors because samples belong to the same animal and that halfudder samples provide a higher range of variation of the parameters studied than whole-udder samples, as mean values are always less extreme than the single values from which the mean is calculated (Le Roux et al., 1995). The presence of IMI reduced clearly the lactose content and the casein:protein ratio, the values being consistent with those reported by others authors (Díaz et al., 1996; Burriel, 1997; Bianchi et al., 2004). However, fat and casein did not change much, even at the half-udder level. The reduction of secreted milk volume caused by IMI could explain this lack of variation because of a concentration effect on these synthesized components (Schultz, 1977; Burriel, 1997). In reports in the literature, the content of fat frequently increases (Burriel, 1997) or remains unchanged by IMI (Díaz et al., 1996; Leitner et al., 2003). With respect to casein, some authors report a reduction (Leitner et al., 2004), an increase (Bianchi et al., 2004) or any variation (Díaz et al., 1996) in its content. In any case, when the casein:protein ratio (independent of milk volume) was determined, it was confirmed to decrease as a result of infection (Bianchi et al., 2004) or elevated SCC (Pellegrini et al., 1997; Pirisi et al., 1999). This finding highlights the negative effect of IMI on cheese yield because, according to Klei et al. (1998) and Auldist et al. (1996), casein:protein ratio is the parameter related to protein that best explains the cheese yield and protein recovery variations. In the present work, the increase of whey proteins in half-udder milk as a result of the increase in permeability of the blood-milk barrier during an IMI is likely to be responsible for the reduction in casein:protein ratio, as described previously (Díaz et al., 1996; Bianchi et al., 2004), because casein content did not vary.

\section{Influence of Production Level and Severity of Infection on Milk Yield Loss}

In the present research, regressions were established to test the influence of production level of animals and infection severity on the mean PPM lost per ewe during the postinfection period. The regressions showed that 
the more productive animals lost more milk due to IMI compared with less productive animals, but these losses were proportional to production levels in healthy conditions. Moreover, predictions were more reliable (higher $\mathrm{R}^{2}$ ) for ewes already infected in wk 1 postpartum than in those infected during lactation. The regressions also indicated that the infection severity affected the mean PPM loss between glands of infected ewes during the postinfection period, both in absolute (PPMDm) and relative terms (PPMDm\%), being more pronounced as $\log _{10} \mathrm{SCCm}$ increased. The association between PPMDm and $\log _{10} \mathrm{SCCm}$ was closer in ewes already infected in wk 1 postpartum than in those infected during lactation. This difference was probably due to the larger number of observations in the whole lactating period. In general, those results were consistent with Gonzalo et al. (1994), who obtained a mathematical model to estimate the individual milk yield as a function of $\log _{10} \mathrm{SCC}$ in sheep, accounting for $73 \%$ of the variation in milk yield. In that study, a total of 8,403 samples from 3,202 ewes from 22 herds were studied, which provided a huge SCC variability corresponding to a great diversity of bacteria species, a factor that is known to affect SCC and milk production (Gonzalo et al., 2002).

\section{Influence of Time From Infection on Milk Yield Loss and Composition Changes}

The results obtained in the study of ewes infected during lactation, at both the half- and whole-udder level, demonstrated that the milk yield decreased dramatically as a result of IMI from the week in which infection was diagnosed. The yield reduction in the infected gland was accompanied by an increase in the yield of the contralateral gland in the week of infection diagnosis. These findings indicate a quick response of mammary secretor tissue to subclinical IMI, both in the infected glands and in their contralateral uninfected ones, according to Knight and Peaker (1991), in goats. Moreover, the milk yield differences in absolute terms remained constant during the $7 \mathrm{wk}$ following the onset of infection. In sheep, fluctuations of milk yield losses within the weeks following infection have not been studied. In cows, investigations have been focused on clinical mastitis, which is always treated after diagnosis. The level of milk production for mastitic cows after treatment does not return completely to the level of that for healthy herdmates (Rajala-Schultz et al., 1999; Wilson et al., 2004).

In ewes already infected in wk 1 postpartum, the absolute differences between glands were evident from the first measurements of PPM and composition parameters, and remained the same during the rest of lactation. This approach allowed us to estimate lacta- tional losses for milk yield and contents in sheep already infected in wk 1 postpartum, and also to determine the consequences of infection along the lactation curve. Although the absolute magnitude of milk yield losses during the lactation period did not change, the relative changes are likely to be increased as lactation advanced because of the typical declining trend of the lactation curve, the consequences of IMI worsening as lactation advanced.

The study of $\log _{10} \mathrm{SCC}$ in milk from ewes infected during lactation showed that in the week of infection, ewes experienced a rapid and strong inflammatory response to IMI that was subsequently slightly moderated. However, the trend of $\log _{10} \mathrm{SCC}$ of ewes already infected in wk 1 postpartum represented the typical curve for this parameter in ovine livestock (Fuertes et al., 1998) in all glands, infected and healthy. The absence of the progressive reduction of $\log _{10} \mathrm{SCC}$ as lactation advanced reinforces the hypothesis that a considerable number of these infections were permanent infections acquired in previous lactations. Finally, in both studies, the differences in the affected milk components between infected and uninfected glands were noticed from the week of infection diagnosis and remained constant during the postinfection period.

\section{CONCLUSIONS}

The individual milk loss as a result of unilateral subclinical IMI acquired during lactation was $15 \%$ in the following $7 \mathrm{wk}$. This loss of milk yield was smaller than it could have been because of $6.6 \%$ more milk being produced by the uninfected half to compensate for the milk lost from the infected gland. This compensatory adaptation highlights the risk of underestimating subclinical mastitis in sheep. Lactational milk yield loss in ewes infected from lambing was 17\%. A rapid response of the mammary secretor tissue to subclinical IMI began in the week in which IMI was diagnosed and remained constant within the rest of lactation. The milk losses were proportional to the production level of ewes, and infection severity affected the milk loss. The present research confirms the previous knowledge about the decrease in lactose content and casein:protein ratio due to subclinical IMI in sheep. Our findings highlight the negative consequences of subclinical IMI on the yield and quality of ewe milk and indicate the importance of subclinical mastitis control and treatment programs for the improvement of udder health status.

\section{ACKNOWLEDGMENTS}

The authors thank the regional government of Valencia ("Generalitat Valenciana") for its support by means of a research fellowship. 


\section{REFERENCES}

Arias, R., B. Oliete, M. Ramón, C. Arias, R. Gallego, V. Montoro, C. Gonzalo, and M. D. Pérez-Guzmán. 2012. Long-term study of environmental effects on test-day somatic cell count and milk yield in Manchega sheep. Small Rumin. Res. 106:92-97.

Ariznabarreta, A., C. Gonzalo, and F. San Primitivo. 2002. Microbiological quality and somatic cell count of ewe milk with special reference to staphylococci. J. Dairy Sci. 85:1370-1375.

Auldist, M. J., S. Coats, B. J. Sutherlands, J. J. Mayes, G. H. McDowell, and G. L. Rogers. 1996. Effects of somatic cell count and stage of lactation on raw milk composition and the yield and quality of Cheddar cheese. J. Dairy Res. 63:269-280.

Bianchi, L., A. Bolla, E. Budelli, A. Caroli, C. Casoli, M. Pauselli, and E. Duranti. 2004. Effect of udder health status and lactation phase on the characteristics of Sardinian ewe milk. J. Dairy Sci. $87: 2401-2408$

Burriel, A. R. 1997. Dynamics of intramammary infection in the sheep caused by coagulase-negative staphylococci and its influence on udder tissue and milk composition. Vet. Rec. 140:419-423.

Burriel, A. R., and A. Wagstaff. 1998. The influence of ewe intramammary infection caused by coagulase-negative staphylococci on the milk constituents total protein, albumin, potassium and sodium. Anim. Sci. 67:499-502.

Cuccuru, C., M. Meloni, E. Sala, L. Scaccabarozzi, C. Locatelli, P. Moroni, and V. Bronzo. 2011. Effects of intramammary infections on somatic cell score and milk yield in Sarda sheep. N. Z. Vet. J. 59:128-131.

Dario, C., V. Laudadio, T. Corsalini, G. Bufano, and C. Buonovaglia. 1996. Subclinical mastitis in sheep: Occurrence, etiology and milk production in different genetic types. Agric. Med. 126:320-325.

Díaz, J. R., R. Muelas, C. Segura, C. Peris, and P. Molina. 1996. Effect of mastitis on milk composition in Manchega ewes: Preliminary results. Pages 305-309 in Somatic Cells and Milk of Small Ruminants. EAAP Publication, Wageningen Pers., Wageningen, the Netherlands.

Fuertes, J. A., C. Gonzalo, J. A. Carriedo, and F. San Primitivo. 1998. Parameters of test day milk yield and milk components for dairy ewes. J. Dairy Sci. 81:1300-1307.

Giadinis, N. D., G. Arsenos, P. Tsakos, V. Psychas, C. I. Dovas, E. Papadopoulos, H. Karatzias, and G. C. Fthenakis. 2012. "Milkdrop syndrome of ewes": Investigation of the causes in dairy sheep in Greece. Small Rumin. Res. 106:33-35.

Gonzalo, C., A. Ariznabarreta, J. A. Carriedo, and F. San Primitivo. 2002. Mammary pathogens and their relationship to somatic cell count and milk yield losses in dairy ewes. J. Dairy Sci. 85:14601467.

Gonzalo, C., J. A. Carriedo, J. A. Baro, and F. San Primitivo. 1994. Factors influencing variation of test day milk yield, somatic cell count, fat and protein in dairy sheep. J. Dairy Sci. 77:1537-1542.

Gonzalo, C., J. A. Tardáguila, L. F. De la Fuente, and F. San Primitivo. 2004. Effects of selective and complete dry therapy on prevalence of intramammary infection and on milk yield in the subsequent lactation in dairy ewes. J. Dairy Res. 71:33-38.

Gröhn, Y. T., S. W. Eicker, and J. A. Hertl. 1995. The association between 305-day milk yield and disease in New York dairy cows. J. Dairy Sci. 78:1693-1702.

Harmon, R. J., R. J. Eberhart, D. E. Jasper, and B. E. Langlois. 1990. Microbiological procedures for the diagnosis of bovine udder infection. Nat. Mastitis Counc. Inc., Arlington, VA.

Hogan, J. S., D. M. Galton, R. J. Harmon, S. C. Nickerson, S. P. Oliver, and J. W. Pankey. 1990. Protocols for evaluating efficacy of postmilking teat dips. J. Dairy Sci. 73:2580-2585.

IDF (International Dairy Federation). 1995. Enumeration of somatic cells. Standard no. 148A. IDF, Brussels, Belgium.

Klei, L., J. Yun, A. Sapru, J. Lynch, D. Barbano, P. Sears, and D. Galton. 1998. Effects of milk somatic cell count on cottage cheese yield and quality. J. Dairy Sci. 81:1205-1213.
Knight, C. H., and M. Peaker. 1991. Mammary gland physiology. Flem. Vet. J. 62(Suppl. 1):33-41.

Le Roux, Y., O. Colin, and F. Laurent. 1995. Proteolysis in samples of quarter milk with varying somatic cell counts. 1. Comparison of some indicators of endogenous proteolysis in milk. J. Dairy Sci. 78:1289-1297.

Leitner, G., M. Chaffer, Y. Caraso, E. Ezra, D. Kababea, M. Winkler, A. Glickman, and A. Saran. 2003. Udder infection and milk somatic cell count, NAGase activity and milk composition-fat, protein and lactose - in Israeli-Assaf and Awassi sheep. Small Rumin. Res. 49:157-164

Leitner, G., M. Chaffer, A. Shamay, F. Shapiro, U. Merin, E. Ezra, A. Saran, and N. Silanikove. 2004. Changes in milk composition as affected by subclinical mastitis in sheep. J. Dairy Sci. 87:46-52.

Leitner, G., M. Chaffer, S. Zamir, T. Mor, A. Glickman, M. Winkler, L. Weisblit, and A. Saran. 2001. Udder disease etiology, milk somatic cell counts and NAGase activity in Israeli Assaf sheep throughout lactation. Small Rumin. Res. 39:107-112.

Leitner, G., N. Silanikove, and U. Merin. 2008. Short communication: Estimate of milk and curd yield loss of sheep and goats with intramammary infection and its relation to somatic cell count. Small Rumin. Res. 74:221-225.

Lucey, S., and G. J. Rowlands. 1984. The association between clinical mastitis and milk yield in dairy cows. Anim. Prod. 39:165-175.

Martí-De Olives, A., Y. Le Roux, J. Rubert-Alemán, C. Peris, and M. P. Molina. 2011. Short communication: Effect of subclinical mastitis on proteolysis in ovine milk. J. Dairy Sci. 94:5369-5374.

Munro, G. L., P. A. Grieve, and B. J. Kitchen. 1984. Effect of mastitis on milk yield, milk composition, processing properties and yield and quality of milk products. Aust. J. Dairy Technol. 39:7-16.

Pellegrini, O., R. Florent, M. Rivemale, and F. Barillet. 1997. Renneting properties of milk from individual ewes: Influence of genetic and nongenetic variables and relationship with physicochemical characteristics. J. Dairy Res. 64:355-366.

Peris, C., J. R. Díaz, N. Fernández, and M. Rodríguez. 1996. Effect of subclinical mastitis on milk yield in Manchega ewes: Preliminary results. Pages 203-206 in Somatic Cells and Milk of Small Ruminants. EAAP Publication, Wageningen Pers., Wageningen, the Netherlands.

Pirisi, A., C. E. Gaspard, G. Piredda, A. Jaubert, and A. Ledda. 1999. Relation entre CCS et les caractéristiques du lait de brebis et de chèvre. Pages 495-500 in Milking and milk production of dairy sheep and goats. EAAP Publication, Wageningen Pers., Wageningen, the Netherlands.

Rajala-Schultz, P. J., Y. T. Gröhn, C. E. McCulloch, and C. L. Guard 1999. Effects of clinical mastitis on milk yield in dairy cows. J. Dairy Sci. 82:1213-1220.

Rulquin, H. 1997. Regulation of the synthesis and the secretion of milk constituents in ruminants. Renc. Rech. Rum. 4:327-338.

Saratsis, P., C. Alexopoulos, A. Tzora, and G. C. Fthenakis. 1999. The effect of experimentally subclinical mastitis on the milk yield of dairy ewes. Small Rumin. Res. 32:205-209.

SAS Institute. 2011. SAS User's Guide: Statistics. Version 9.2 ed. SAS Inst. Inc., Cary, NC.

Schultz, L. H. 1977. Somatic cells in milk-Physiological aspects and relationship to amount and composition of milk. J. Food Prot. 40:125-131.

Sloth, K. H. M. N., N. C. Friggens, P. Løvendahl, P. H. Andersen, J. Jensen, and K. L. Ingvartsen. 2003. Potential for improving description of bovine udder health status by combined analysis of milk parameters. J. Dairy Sci. 86:1221-1232.

Wilson, D. J., R. N. González, J. Hertl, H. F. Schulte, G. J. Bennett, Y. H. Schukken, and Y. T. Gröhn. 2004. Effect of clinical mastitis on the lactation curve: A mixed model estimation using daily milk weights. J. Dairy Sci. 87:2073-2084.

Woolford, M. W. 1985. The relationship between mastitis and milk yield. Kieler Milchwirtsch. Forsch. 37:224-232. 